\title{
Genetic Diversity and Population Structure in Elaeidobius kamerunicus (Coleoptera: Curculionidae) Inferred from mtDNA COI and Microsatellite Markers
}

\author{
Ruomenson DJ Bakara ${ }^{1}$ Van Basten Tambunan ${ }^{1,2^{*}}$,Ardha Apriyanto ${ }^{2}$, Yayi M \\ Kusumah $^{1}$, Bandung Sahari ${ }^{2}$, Damayanti Buchori ${ }^{1}$ \\ ${ }^{1}$ Department of Plant Protection, Faculty of Agriculture, IPB University, Dramaga, Bogor, West Java 16680, Indonesia \\ ${ }^{2}$ PT Astra Agro Lestari, Jakarta \\ *Corresponding author. Email: vanbastentambunan24@gmail.com
}

\begin{abstract}
Elaeidobius kamerunicus Faust (Coleoptera: Curculionidae) is widely known as the main pollinator of oil palm. Although economically important,the population genetics of this pollinator have remained relatively unexplored. This study explores population genetic structure and contemporary gene flow in E.kamerunicus in Indonesian provinces and attempts to place observed patterns within the broader geographical context. Based on combined data from mtDNA cytochrome oxidase subunit I (COI) sequences and 11 SSR loci obtained from 32 individuals located in 11 province and 16 sites, overall genetic structuring was low. The study suggested a close relationship of individuals between close provinces but some of data showed that individuals from provinces with far geographical also shared some close relationship. The expansion history of this species, including likely human-mediated dispersal, may have played a role in shaping the observed weak structure detected in this study. The information resulted from this analysis of gene flow and population structure has broad implications for monitoring and management of this pollinator, especially in oil palm plantations in Indonesia. Future studies should concentrate efforts on sampling of African and South-East Asian populations, which would enable better inferences of the ancestral location of E.kamerunicus and its invasion history into and throughout world.
\end{abstract}

Keywords: genetic diversity, geographical, mtDNA, population, SSR

\section{INTRODUCTION}

Insect pollinator behaviour in foraging on flowers influenced by intrinsic (e.g., thermo-regulation abilities) and extrinsic (e.g., ambient temperature or light intensity) factors [1-5]. Elaeis guineensis Jacq. produces unisexual male and female inflorescences [6], which are produced in alternate cycles. Thus, oil palm reproduction requires cross-pollination carried out by several agents, one of which is an insect [7]. Recently, the beetles in the Curculionidae and Nitidulidae (Coleoptera) families are the most important insect pollinators of oil palms. These pollinators have a mutualistic symbiosis with oil palm; the post anthesis male inflorescences serve as brood sites, and the female inflorescences are pollinated by deceit, as explained in the following paragraph.

The underlying pollination process is mediated by the release of inflorescence odour. Female inflorescences of $E$. guineensis emit an anise-like fragrance similar to the fragrance emitted by the male inflorescences at anthesis to attract insects [8-10]. Pollination by insect is critical for an economically sustainable oil palm industry because it increases fruit set and consequently oil yields $[11,12]$. The oil palm industry is dependent on the artificial reinforcement of pollination, using human-assisted pollination or the introduction of insects in areas in which they are absent [13]. Thus, the study of the pollination system of Elaeis spp and the interactions with insect pollinators of these palms may help improve pollination in oil palm plantations. The biology of the pollinators of oil palm species, particularly the timing of visits to inflorescences, is not well understood. To date, most of the published studies on insect activity on oil palm inflorescences have focused on Elaeidobius weevils, including Elaeidobius kamerunicus Faust and E. subvittatus Faust, and on a beetle Mystrops costaricensis Gillogly (Coleoptera: Nitidulidae). E. kamerunicus and E. subvittatus are both reportedly visitors on inflorescences of E. guineensis in Africa, their country of origin $[14,15]$ and in regions where these species were artificially introduced, such as Asia and South America [16-21]. Reported that E. subvittatus also showed morning activity on E. oleifera inflorescences in South America [11, 20]. However, a short second period of activity at the end of the day was observed for E. kamerunicus in West Africa [15] and on Hainan Island, China [17].

Information regarding genetic diversity, genetic structure and gene flow are key issues when developing bio-management strategies of these pollinator species 
especially E.kamerunicus [22, 23]. The mitochondrial (mtDNA) cytochrome oxidase subunit I (COI) gene is easily amplified [24], maternally inherited and relatively fast-evolving, which allows derivation of recent femalespecific evolutionary histories In contrast, microsatellites (SSRs) are nuclear, bi-parentally inherited, highly polymorphic and easy to isolate, making them particularly informative in the study of contemporary biological invasions [25, 26]. Thus, these two sets of molecular markers are indispensable tools to study the population genetic structure of insect pollinator, including $E$. kamerunicus species.

Taken together, this study provides foundational data for understanding the population dynamics and genetic structure of E. kamerunicus, which will contribute greatly toward monitoring and management of this pollinator, especially in oil palm plantations in Indonesia.

\subsection{Material and Methods}

\subsubsection{Sample collection}

The E.kamerunicus samples were collected from oil palm female inflorescence during its anthesis from 11 provinces and 16 sites in Indonesia (Table 1). All weevils were stored in $100 \%$ ethanol at $-20{ }^{\circ} \mathrm{C}$ prior to DNA extraction.

\subsubsection{DNA extraction}

Total genomic DNA was extracted using the gSYNC DNA Extraction Kit (Geneaid) following the manufacturer's instructions. The quality and quantity of the extracted DNA were evaluated using a Nanodrop ND1000 spectrophotometer (Nano-Drop Technologies Inc.) and by electrophoresis of the sample DNA in $1 \%$ agarose gel.

\subsubsection{Species identification using mtDNA COI}

Cytochrome c oxidase subunit 1 (COI) primers were used to confirm the identification of the insect. A 708-base pair (bp) fragment of COI was amplified using primers COI E.kam F (5' - TTGGAGGATTTGGGAATTGACT3') and COI E.kam R (5'-TTGCTGAAGTAAAATAT GCCCGT-3'). The COI genes were amplified using a Veriti Thermal Cycler (Applied Bio system, USA). PCR was performed in $50 \mu \mathrm{L}$ of a reaction containing each of 1 $\mu \mathrm{L} 0.25 \mathrm{mM}$ forward and reverse primer, $25 \mu \mathrm{L}$ Kapa $2 \mathrm{G}$ Fast Master Mix (Kapa Biosystem, USA), $22 \mu \mathrm{L}$ nuclease free water and $1 \mu \mathrm{L}$ of mycelium template. An initial denaturation step for $3 \mathrm{~min}$ at $95{ }^{\circ} \mathrm{C}$ was followed by 35 cycles of denaturation for $15 \mathrm{~s}$ at $95{ }^{\circ} \mathrm{C}$, annealing for $10 \mathrm{~s}$ at $55{ }^{\circ} \mathrm{C}$ and extension for $10 \mathrm{~s}$ at $72{ }^{\circ} \mathrm{C}$, with a final extension step of $5 \mathrm{~min}$ at $72^{\circ} \mathrm{C}$. The PCR products were visualized by agarose gel electrophoresis. Then, it is directly sequenced at First Base, Malaysia by automated DNA sequencing with ABI 3730 XL (Applied Biosystems, USA) using COI E.kam primers especially for E. kamerunicus, which has been designed and optimized by Astra Agro Lestari based on GenBank.

DNA sequences were edited and aligned using Geneious Prime (www.geneious.com). Sequence analyses and specimen identification were done by inputting the trimmed sequence both in NCBI's BLAST tool. Molecular Identification was made based on percent similarity result. An unrooted phylogenetic tree using Randomized Accelerated Maximum Likelihood (RAxML) method [27] was created in Geneious Prime Software. Also, haplotype networks construction was inferred using Minimum Spanning Network (MSN) method Bandelt et al. (1999) [28] and was drawn using POPART software [29].

\subsubsection{Population study using SSR genotyping}

The genotyping stage is carried out to determine the size of the allele formed from each individual and the allele frequency in each population. in this study the genotype used Eleven SSR marker loci (Table 2.) At this stage, amplification was carried out by PCR method in all insect individuals using primers. PCR was performed in $50 \mu \mathrm{L}$ of a reaction containing each of $1 \mu \mathrm{L} 0.25 \mathrm{mM}$ forward and reverse primer, $25 \mu \mathrm{L}$ Kapa $3 \mathrm{G}$ Fast Master Mix (Kapa Biosystem, USA), $22 \mu \mathrm{L}$ nuclease free water and $1 \mu \mathrm{L}$ of mycelium template. An initial denaturation step for 3 min at $95{ }^{\circ} \mathrm{C}$ was followed by 35 cycles of denaturation for $20 \mathrm{~s}$ at $95{ }^{\circ} \mathrm{C}$, annealing for $10 \mathrm{~s}$ at $51{ }^{\circ} \mathrm{C}$ and extension for $15 \mathrm{~s}$ at $72{ }^{\circ} \mathrm{C}$, with a final extension step of $15 \mathrm{~s}$ at $72{ }^{\circ} \mathrm{C}$ and temporary stored at $4{ }^{\circ} \mathrm{C}$. The amplified sample was then visualized with the Automated CE System Fragment Analyzer using dsDNA 910 Reagent Kit and Prosize 3.0 software. As much as $2 \mu \mathrm{L}$ of PCR samples were taken and given $22 \mu \mathrm{L}$ of $1 \mathrm{X}$ dilution buffer. Separating gel used is a polyacrylamides gel that has been given intercalating dye.

Allele scoring data were tabulated using Microsoft Office Excel. CERVUS version 3.0 and GENALEX version 6.3 were used for analysed population genetic parameters. Principal component analyses were done using DARWIN Software version 6.0.013. Clustering analysis was conducted using Discriminant analysis of principal components (DAPC) as mentioned by Jombart et al. [30] inside an $\mathrm{R}$ package adegenet [31, 32].

Haplotype networks construction was inferred using Minimum Spanning Network (MSN) method [27] and Briva distance calculation [33]. The results then were drawn using an R package poppr [34].

The population structures were determined using the STRUCTURE software version 2.3.4 and STRUCTURE SELECTOR version web [35]. The approach by Puechmaille [36] and Evanno et al. [37] were used to select the appropriate $\mathrm{K}$ clusters for the studied populations. The Structure population was drawn using CLUMPAK software [38]. 
Table 1 List of samples used in this study

\begin{tabular}{|c|c|c|c|c|c|c|c|}
\hline No. & Province & Island & Site & City & Sample & Sex & No. Ind \\
\hline 1 & \multirow{4}{*}{$\begin{array}{c}\text { Kalimantan } \\
\text { Tengah }\end{array}$} & \multirow{10}{*}{ Kalimantan } & NAL & \multirow[t]{2}{*}{ Kumai } & NALB & Female & 1 \\
\hline 2 & & & NAL & & NALJ & Male & 1 \\
\hline 3 & & & GSY & Kumai & GSYB & Female & 1 \\
\hline 4 & & & GSY & & GSYJ & Male & 1 \\
\hline 5 & \multirow{4}{*}{$\begin{array}{c}\text { Kalimantan } \\
\text { Barat }\end{array}$} & & KB & \multirow[t]{2}{*}{ Kalbar } & KBRB & Female & 1 \\
\hline 6 & & & KB & & KBRJ & Male & 1 \\
\hline 7 & & & KTP & \multirow[t]{2}{*}{ Ketapang } & KTPB & Female & 1 \\
\hline 8 & & & KTP & & KTPJ & Male & 1 \\
\hline 9 & \multirow{2}{*}{$\begin{array}{l}\text { Kalimantan } \\
\text { Timur }\end{array}$} & & KED & \multirow[t]{2}{*}{ Balikpapan } & KEDB & Female & 1 \\
\hline 10 & & & KED & & KEDJ & Male & 1 \\
\hline 11 & \multirow{2}{*}{ Aceh } & \multirow{10}{*}{ Sumatra } & PLB & \multirow[t]{2}{*}{ Aceh } & PLBB & Female & 1 \\
\hline 12 & & & PLB & & PLBJ & Male & 1 \\
\hline 13 & \multirow{2}{*}{ Sumatra Utara } & & STR & \multirow[t]{2}{*}{ Siantar } & STRB & Female & 1 \\
\hline 14 & & & STR & & STRJ & Male & 1 \\
\hline 15 & \multirow{4}{*}{ Riau } & & EDI & \multirow[t]{2}{*}{ Pekanbaru } & EDIB & Female & 1 \\
\hline 16 & & & EDI & & EDIJ & Male & 1 \\
\hline 17 & & & AIM & \multirow[t]{2}{*}{ Air Molek } & AIMB & Female & 1 \\
\hline 18 & & & AIM & & AIMJ & Male & 1 \\
\hline 19 & \multirow{2}{*}{ Sumatra Selatan } & & PB & \multirow[t]{2}{*}{ Palembang } & PBB & Female & 1 \\
\hline 20 & & & PB & & PBJ & Male & 1 \\
\hline 21 & \multirow{2}{*}{ Sulawesi Barat } & \multirow{4}{*}{ Sulawesi } & SLT & \multirow[t]{2}{*}{ Letawa } & SLTB & Female & 1 \\
\hline 22 & & & SLT & & SLTJ & Male & 1 \\
\hline 23 & \multirow{2}{*}{$\begin{array}{l}\text { Sulawesi } \\
\text { Tengah }\end{array}$} & & ANA & \multirow[t]{2}{*}{ Morowali } & ANAB & Female & 1 \\
\hline 24 & & & ANA & & ANAJ & Male & 1 \\
\hline 25 & \multirow{6}{*}{ Jawa Barat } & \multirow{6}{*}{ Java } & BGR & \multirow[t]{2}{*}{ Bogor } & BGRB & Female & 1 \\
\hline 26 & & & BGR & & BGRJ & Male & 1 \\
\hline 27 & & & CSL & \multirow[t]{2}{*}{ Cisalak } & CSLB & Female & 1 \\
\hline 28 & & & CSL & & CSLJ & Male & 1 \\
\hline 29 & & & CJR & \multirow[t]{2}{*}{ Cianjur } & CJRB & Female & 1 \\
\hline 30 & & & CJR & & CJRJ & Male & 1 \\
\hline 31 & \multirow{2}{*}{ Papua } & & NBR & Nabire & NBRB & Female & 1 \\
\hline 32 & & Papua & NBR & & NBRJ & Male & 1 \\
\hline
\end{tabular}

\subsection{Our Contribution}

This paper discusses genetic diversity and population structure of E. kamerunicus in Indonesia.

\subsection{Paper Structure}

The rest of the paper is constructed as follows: section 2 , serves description of allelic pattern, phylogenetic approach, and population structure of E. kemrunicus, and section 3 concludes the results of this paper. 
Table 2 List of SSR marker used in this study

\begin{tabular}{|c|c|c|c|c|c|c|c|}
\hline Locus & Forward (5'-3') & Reverse (5'-3') & Sequence & Motif & Repeat & Lenght & $\begin{array}{l}\text { Product } \\
\quad \text { (bp) }\end{array}$ \\
\hline ssr-12 & $\begin{array}{c}\text { AGATGGACG } \\
\text { TTCTACATTG } \\
\text { GC }\end{array}$ & $\begin{array}{l}\text { GAACGAAGAA } \\
\text { ACTGTGGTGCC }\end{array}$ & scaffold-25 & TG & 13 & 26 & 113 \\
\hline ssr-13 & $\begin{array}{c}\text { GGTTCCAAAC } \\
\text { AAGCATCGG } \\
\text { G }\end{array}$ & $\begin{array}{c}\text { TTATCTCCCGA } \\
\text { AGCGACTGC }\end{array}$ & scaffold-25 & $\mathrm{ACC}$ & 5 & 15 & 128 \\
\hline ssr-137 & $\begin{array}{c}\text { AAAAACACT } \\
\text { ACGGACTGC } \\
\text { GC }\end{array}$ & $\begin{array}{l}\text { GGGTCTAAAG } \\
\text { GCCGTAGTCG }\end{array}$ & scaffold-547 & TG & 8 & 16 & 132 \\
\hline ssr-159 & $\begin{array}{c}\text { GCTCAGCTTT } \\
\text { TCCAATAATC } \\
\text { GTCC }\end{array}$ & $\begin{array}{c}\text { GTGGAGTATAC } \\
\text { AGCAGGGGG }\end{array}$ & scaffold-637 & TA & 7 & 14 & 110 \\
\hline ssr-16 & $\begin{array}{c}\text { TCGTTGTTAT } \\
\text { CCTCTCGTCG } \\
\text { G }\end{array}$ & $\begin{array}{c}\text { GCTGGAGATCG } \\
\text { TCGTTAAACG }\end{array}$ & scaffold-25 & TCG & 5 & 15 & 100 \\
\hline ssr-17 & $\begin{array}{c}\text { CTTCGGGTGC } \\
\text { TTTTAAAAAG } \\
\text { GG } \\
\end{array}$ & $\begin{array}{c}\text { TGTAGTATAGA } \\
\text { GGTAGATAATC } \\
\text { GAGCC } \\
\end{array}$ & scaffold-27 & ATTG & 4 & 16 & 152 \\
\hline ssr-192 & $\begin{array}{c}\text { TTGTTCAAAA } \\
\text { TGAGCGGCG } \\
\mathrm{C} \\
\end{array}$ & $\begin{array}{l}\text { GGACCAACAA } \\
\text { CGCATTTTGC }\end{array}$ & scaffold-833 & $\mathrm{AC}$ & 7 & 14 & 148 \\
\hline ssr-208 & $\begin{array}{c}\text { TGACATTTAT } \\
\text { CATTGCATAG } \\
\text { GTGGC }\end{array}$ & $\begin{array}{l}\text { ATTGGAACCTA } \\
\text { AGATCACCAGC }\end{array}$ & scaffold-901 & AT & 7 & 14 & 118 \\
\hline ssr-27 & $\begin{array}{l}\text { TTGACGAGTC } \\
\text { CGGTTTTTGC }\end{array}$ & $\begin{array}{c}\text { GCGGAATCACT } \\
\text { CTCGACTACG }\end{array}$ & scaffold-51 & GTT & 7 & 21 & 202 \\
\hline ssr-42 & $\begin{array}{c}\text { CTATTCAGAT } \\
\text { TGGGCTTGGG } \\
\text { C }\end{array}$ & $\begin{array}{l}\text { TTATGGCCCAT } \\
\text { GTAAGCATCC }\end{array}$ & scaffold-90 & AT & 7 & 14 & 107 \\
\hline ssr-56 & $\begin{array}{c}\text { AACATCGAC } \\
\text { GCGAGAAAT } \\
\text { CG } \\
\end{array}$ & $\begin{array}{c}\text { TGTATAGCATC } \\
\text { CGTCACAATAG } \\
\text { GG }\end{array}$ & scaffold-141 & $\mathrm{AAG}$ & 5 & 15 & 123 \\
\hline
\end{tabular}

\section{RESULTS AND DISCUSSION}

In this study we used Mitochondrial markers (COI gene) and Nuclear Markers (SSR) as tool to elaborate genetic diversity and population structure of E.kamerunicus. We will discuss based on these two different markers.

\subsection{Mitochondrial markers}

Mitochondrial DNA (mtDNA) analysis is generally assumed to be more powerful than allozyme and nuclear DNA markers for revealing historical gene flow versus current gene flow [39]. The cytochrome oxidase I (COI) and II (COII) genes of the mtDNA are useful for the measurement of genetic variation, haplotype identification, construction of phylogenies and population genetic studies in insects [40, 41].

Recently, region near the $5^{\prime}$ end of the mitochondrial COI gene was used as DNA Barcoding standard for animal kingdom, including insect [42, 43]. DNA barcoding, in a broad sense, is simply the use of short, standardized genomic segments as markers for species recognition. Just as species differ in morphology, ecology, and behaviour, they also differ in their DNA sequences.

In this study we will discuss about phylogenetic approach and network approach also combine the result of both approaches. 
Abantiadinus nodipennis (KX191194), Sphenophorus sp.

\subsubsection{Analysis of phylogenetic approach}

The phylogenetic tree was inferred from a 708-bp fragment of COI from 32 individuals of E.kamerunicus collected in Indonesia and another related insect COI from Gen Bank NCBI database as reference (Figure 1). There are no previous information about E.kamerunicus COI sequence in GenBank NCBI database or BOLD database. Therefore, this is the first study using a COI fragment as DNA barcoding technique for Species Identification of this species. The COI sequence result from this study already deposited in the GenBank NCBI database for future study. We used several reference species to build phylogenetic tree this include Araucarius major (AY040285), Amorphocerus talpa (EU310754),
BYU-CO246 (GU176342), Naupactus xanthographus

(GU176345), Hylobitelus xiaoi (JX847496),

Curculionidae sp. MT-2014 (KM244695), Curculionidae sp. JH-2016 (KU531398), Eucryptorrhynchus chinensis (KP410324), Eucryptorrhynchus brandti (KP455482), Sphenophorus sp. BYU-CO246 (NC_018351), Rhynchophorus ferrugineus (NC_028535), Aegorhinus superciliosus (NC_027577), Hylobitelus xiaoi (NC_022680), Naupactus xanthographus (NC_018354), Apodrosus epipolevatus (HQ891423), Laemophloeus fasciatus (KP134161), Exophthalmus pictus fulvovirgatus (KT350641), Exophthalmus pictus (KT350642), Scepticus tigrinus (LC108870), Scepticus uniformis (LC108925), Meotiorhynchus querendus (LC108949). Figure 1 shows

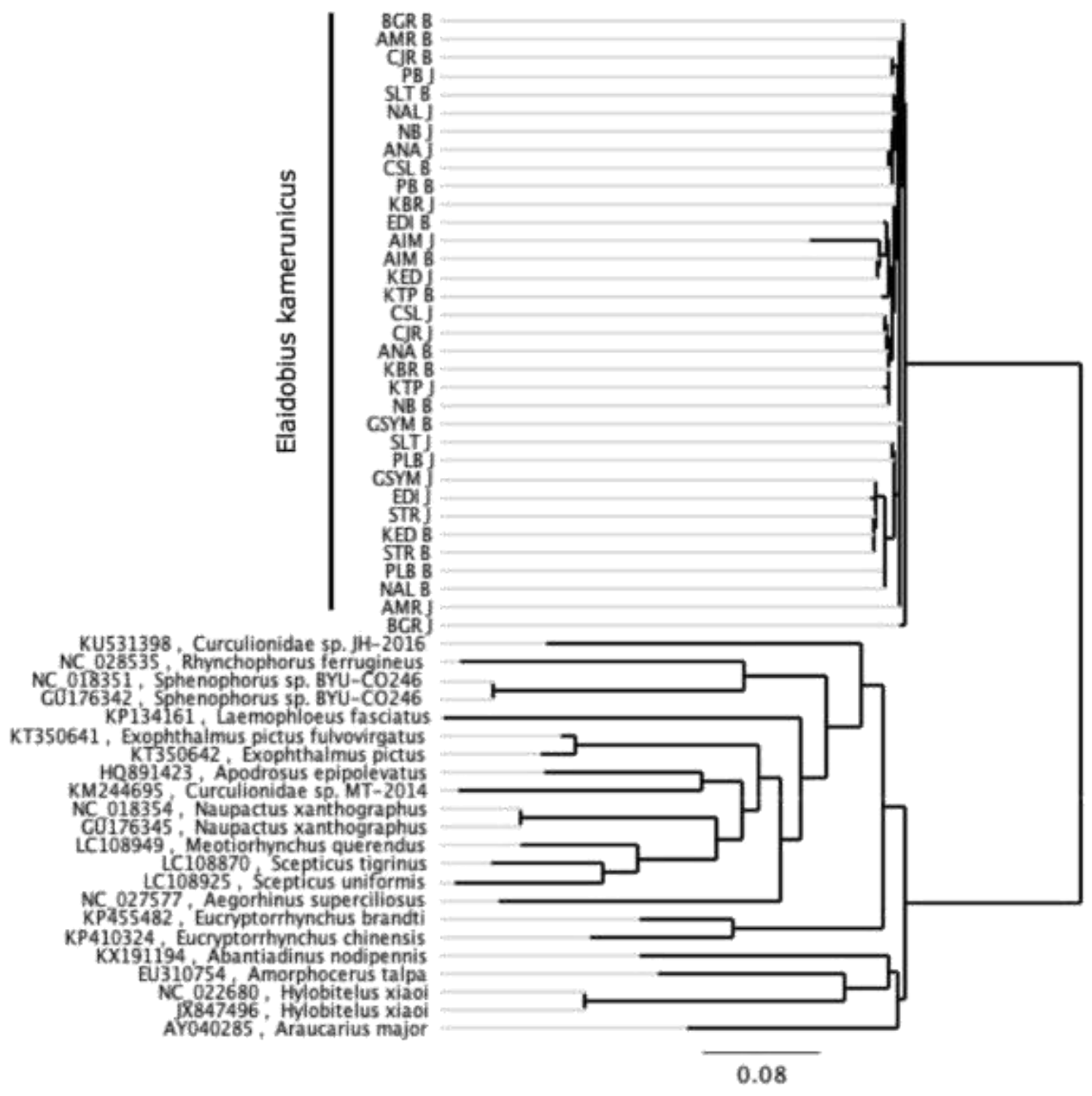

Figure 1 Phylogenetic Tree using RAxML method 
that the COI fragments from E.kamerunicus samples were clustered into one cluster compared with reference from another related species. Based on this result we can conclude that COI gene from E.kamerunicus is unique and conserved. This COI gene can be used as DNA barcode for identifying E.kamerunicus species, especially using our primers mentioned in this study.

\subsubsection{Analysis of network approach}

Minimum spanning network (MSN) was used in this study in order to elucidate evolutionary relationships among E. kamerunicus cryptic species in Indonesia. The MSN was constructed from 32 haplotypes demonstrated that several haplotypes were highly common and shared by many locations. As we can see in the Figure 2.

The haplotype for one location can be consisted from different locations. From this result we can conclude that there is no genetic bottleneck in sampling population or geographic isolation. The population in this study still in mixed haplotype.

\subsection{Nuclear Markers}

Understanding population structure and gene flow among regions are very important aspects in the biomanagement of this species. In this study, we obtained data from both mitochondrial and nuclear DNA markers of an oil palm pollinator weevil.

The nuclear loci are essential as well, because they represent neutral and paternal inheritance. Particularly, non-coding intron sequences offer potentially powerful genetic markers, since they have a number of traits that are suitable for molecular phylogenies

\subsubsection{Analysis of allelic pattern}

The result of allelic frequency of each marker can be seen in Table 3. It is showed that the marker used in this study is highly polymorphic.

The number of alleles among all individuals at the 16 selected SSR loci ranged from 3 to 26 . The observed heterozygosity (Hobs) ranged between 0to 1.000, expected heterozygosity (Hexp) ranged between 0.276 to 0.949 and polymorphism information content (PIC) ranged between 0.248 to 0.930 respectively.

The program CERVUS found significant deviations from HWE for 13 loci and estimated a frequency of null alleles ranging from -0.2707 to 0.1218 for the individual loci. Null alleles can be confirmed through departure from Mendelian segregation ratio in progeny sets. Detection from expected segregation ratios were tested for each locus in each progeny family.

The result of allelic pattern across population can be seen in Figure 3. It is shown that the heterozygosity $(\mathrm{He})$ between population range from 0.35 to 0.65 . With the highest was in West Java (Jawa Barat) population and the lowest was in Central Sulawesi (Sulawesi Tengah) population.

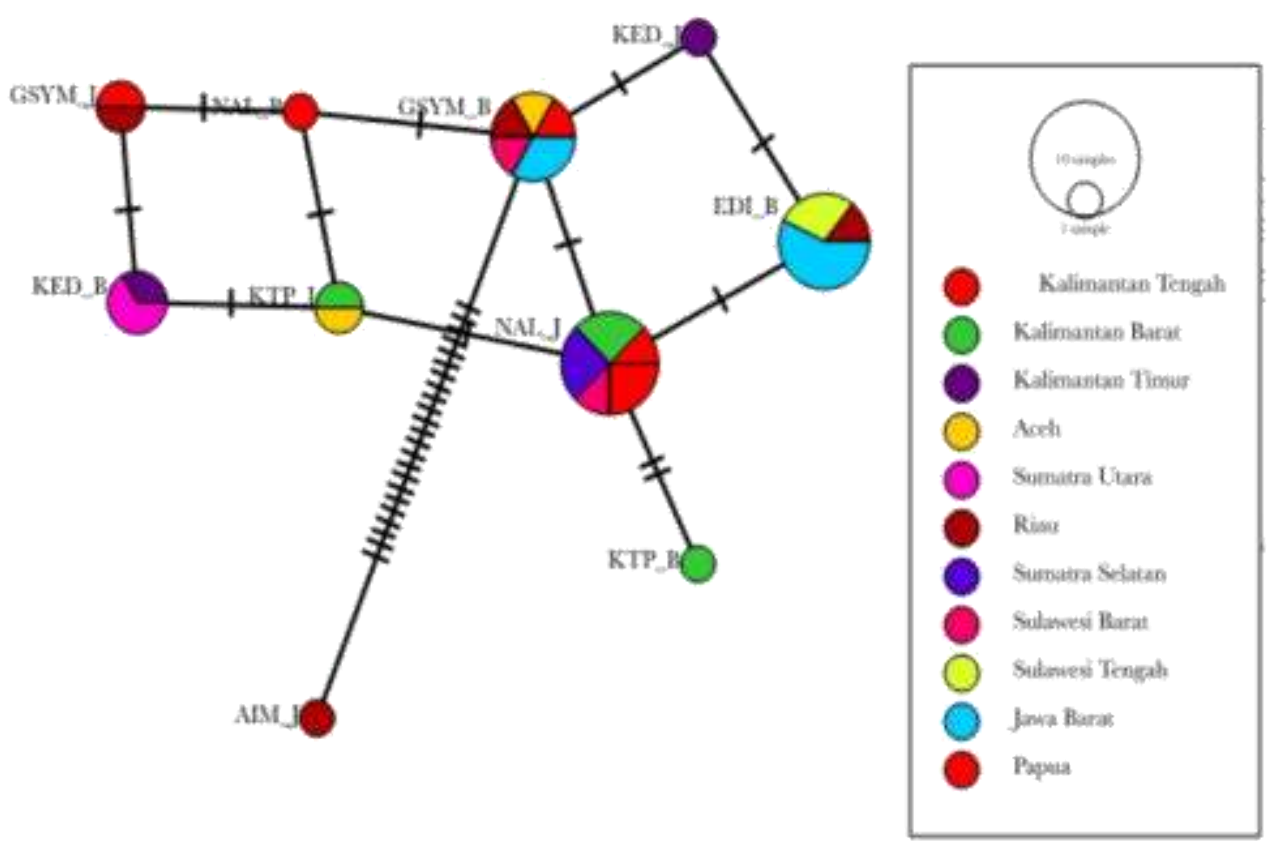

Figure 2 Minimum spanning network (MSN) inferred from samples mitochondrial sequences COI 
Table 3 Allelic frequency and polymorphic information content

\begin{tabular}{|c|c|c|c|c|c|c|c|}
\hline Locus & K* & N* & Hobs* & Hexp* & PIC* & HW* & F(Null)* \\
\hline Locus-SSR12 & 20 & 32 & 1.000 & 0.892 & 0.868 & ND & -0.0717 \\
\hline Locus-SSR13 & 8 & 32 & 1.000 & 0.821 & 0.781 & ND & -0.1096 \\
\hline Locus-SSR16 & 3 & 32 & 0.000 & 0.276 & 0.248 & ND & 0.9725 \\
\hline Locus-SSR17 & 12 & 32 & 1.000 & 0.861 & 0.832 & ND & -0.0919 \\
\hline Locus-SSR27 & 26 & 32 & 0.906 & 0.949 & 0.930 & ND & 0.0143 \\
\hline Locus-SSR142 & 10 & 32 & 1.000 & 0.829 & 0.795 & ND & -0.1111 \\
\hline Locus-SSR56 & 3 & 32 & 0.000 & 0.484 & 0.427 & ND & 0.9991 \\
\hline Locus-SSR137 & 10 & 32 & 0.000 & 0.766 & 0.725 & $* * *$ & 1 \\
\hline Locus-SSR159 & 12 & 32 & 0.969 & 0.861 & 0.830 & ND & -0.0748 \\
\hline Locus-SSR192 & 12 & 32 & 0.875 & 0.899 & 0.874 & ND & 0.0023 \\
\hline Locus-SSR208 & 6 & 32 & 0.000 & 0.468 & 0.437 & ND & 0.9987 \\
\hline
\end{tabular}

$* \mathrm{~K}=$ Number of alleles detected; $\mathrm{N}=$ Number of individuals, Hobs = Observed Heterozigosity, Hexp = Expected Heterozigosity, HW = HardyWeinberg equilibrium test; $\mathrm{F}($ Null $)=$ Null allele frequency estimate

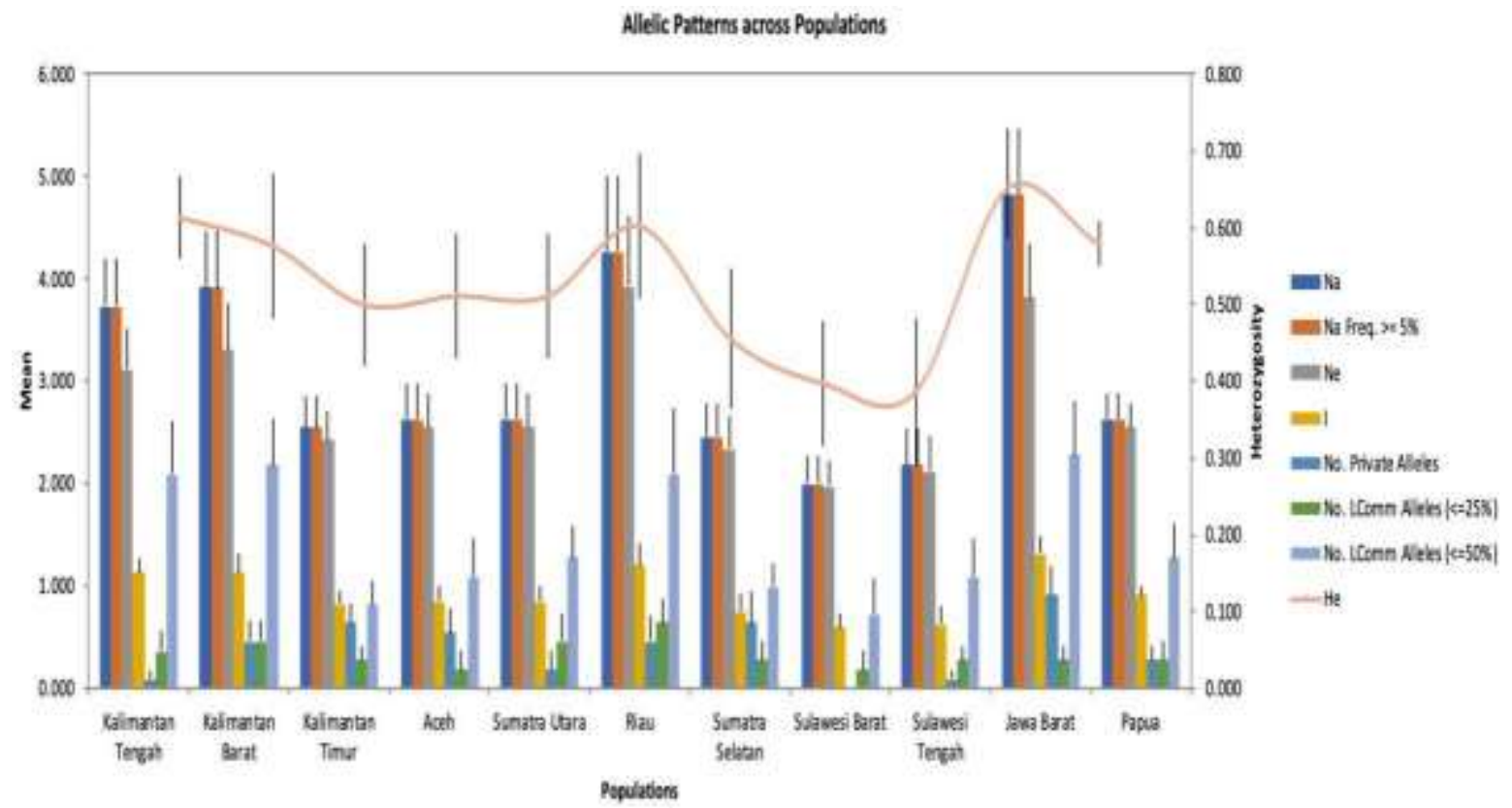

Figure 3 Allelic Pattern across population. He: Heterozigosity, Na: Number of Alleles, Na Freq > = 5\% ; Number of Alleles more than 5\%, Ne : Number of Effective Alleles, I = Shanon Index

\subsubsection{Clustering analysis}

Clustering analysis was conducted in order to find population cluster between sample tested in this study. We used Principal Component Analysis (PCA) and
Discriminant analysis of principal components (DAPC). Principal component analysis (PCA) is a statistical procedure that uses an orthogonal transformation to convert a set of observations of possibly correlated variables (entities each of which takes on various 
Minimum spanning networks (MSN) are a great way to visualize relationships among individuals in our data. In can describe the relationship of each individual or population. As we can see from Figure 6 that the individuals from same sites were genetically similar (clustered). Also, we can elaborate the haplotype networking based on this result. It is clear that the haplotype form one site or island was not originated from one haplotype. Therefore, this result supports previous results that the genetic population between islands is not isolated by geographic $[44,45]$. E.kamerunicus was not in geographic isolation. We then look closer to compare one population with another population. It can be seen in Figure 5 that the population genetic from same island was quite similar. For instance, the Sumatran populations genetic were in close distance except Aceh populations.

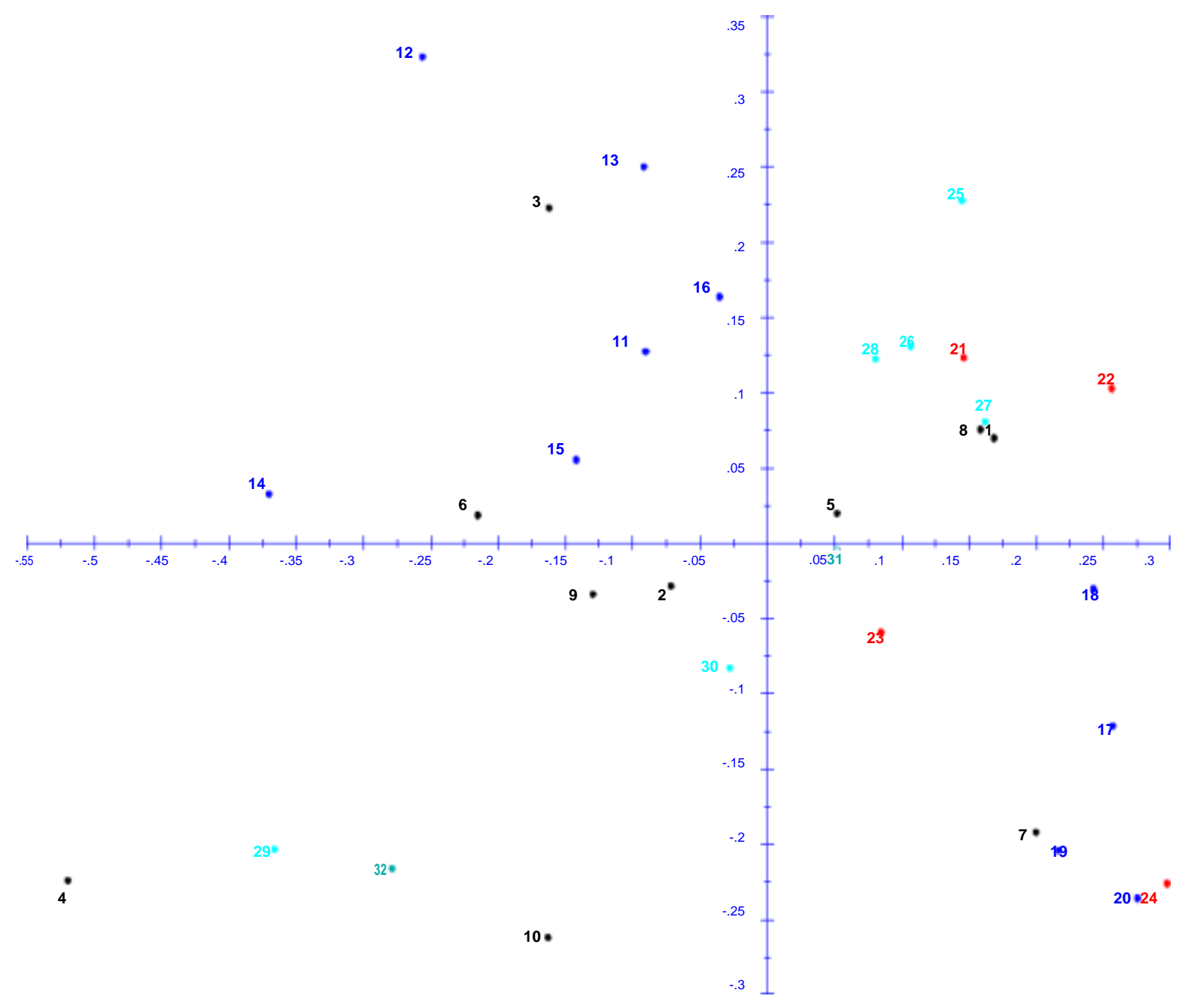

Figure 4 Principal Component Analysis. Black: Sumatra, Red: Sulawesi, Dark Blue: Kalimantan, Light Blue: Jawa, Green: Papua 


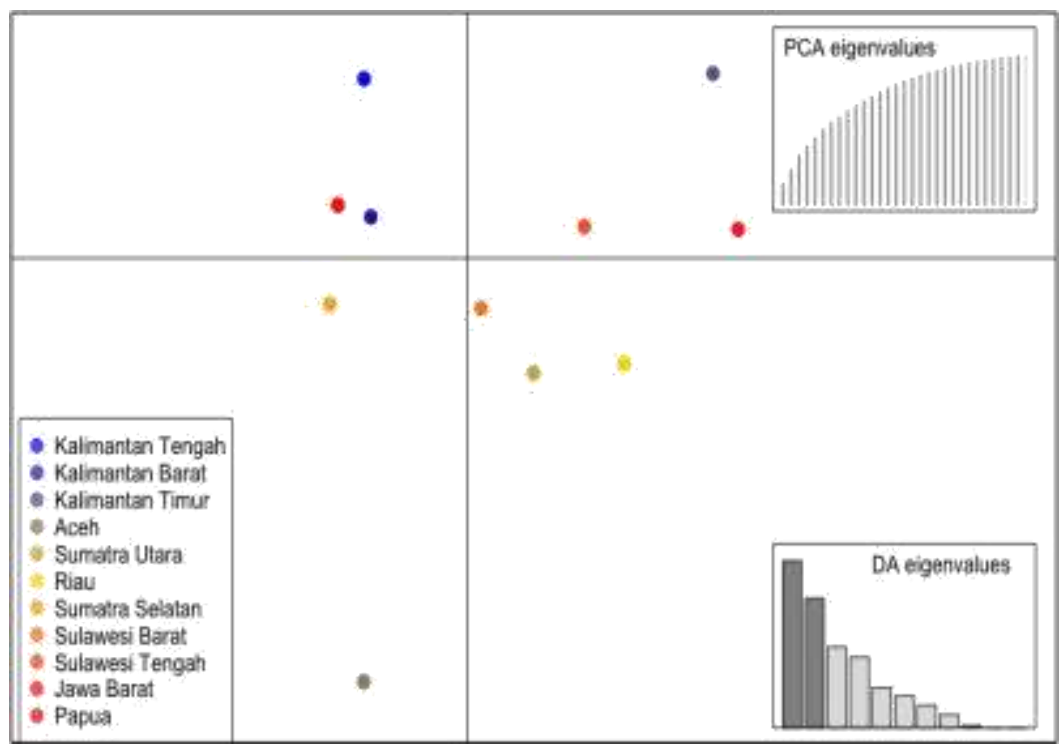

Figure 5 Discriminant analysis of principal components (DAPC)

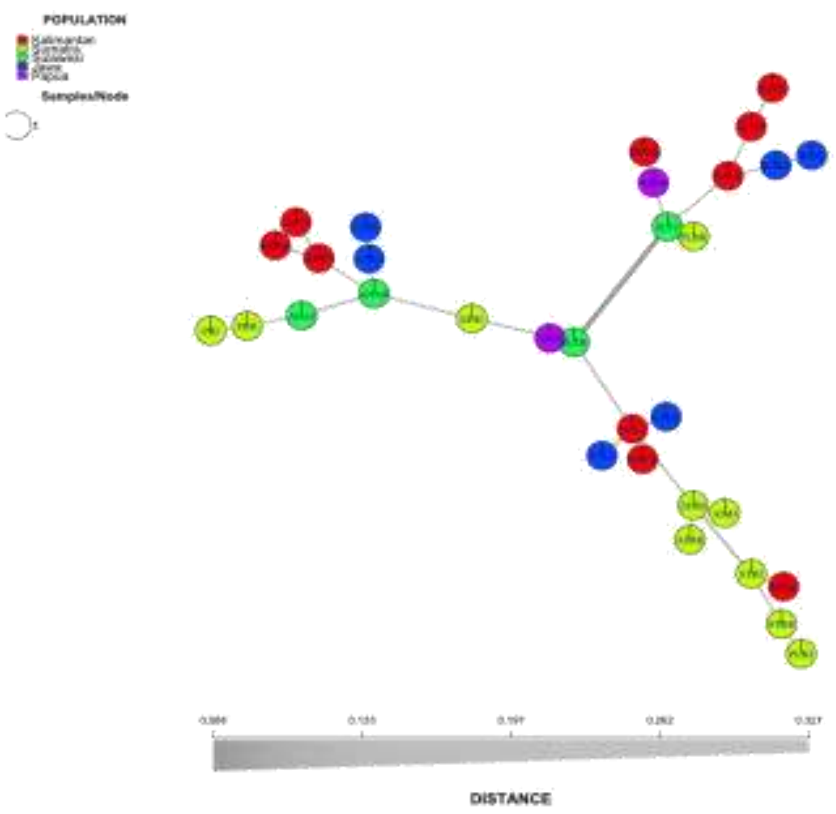

Figure 6 Minimum spanning Network based on SSR marker

\subsection{Analysis of Population Structure}

In this study we applied two sets of molecular markers to avoid any bias due to the use of only a single marker. In order to find population structure and how many genetic groups in our sample, we conduct population structure analysis. We used the method from [36] and [37] in order to find the best $\mathrm{K}$.

The result from Puechmaille Method showed that the best $\mathrm{K}$ was 5 also Evano Method showed that the best $\mathrm{K}$ was 7. Therefore, we will use both results to create population structure plots. The result can be seen in Figure 8.

Based on this result, we can see that at least there are 5 or 7 cluster populations from the sample. The only clear cluster populations were from Sulawesi Island. In addition, the genetic from another islands seems admixture from each other. Also based on these results, supporting that we could not find clear geographic isolation between islands and between samples in this study. 

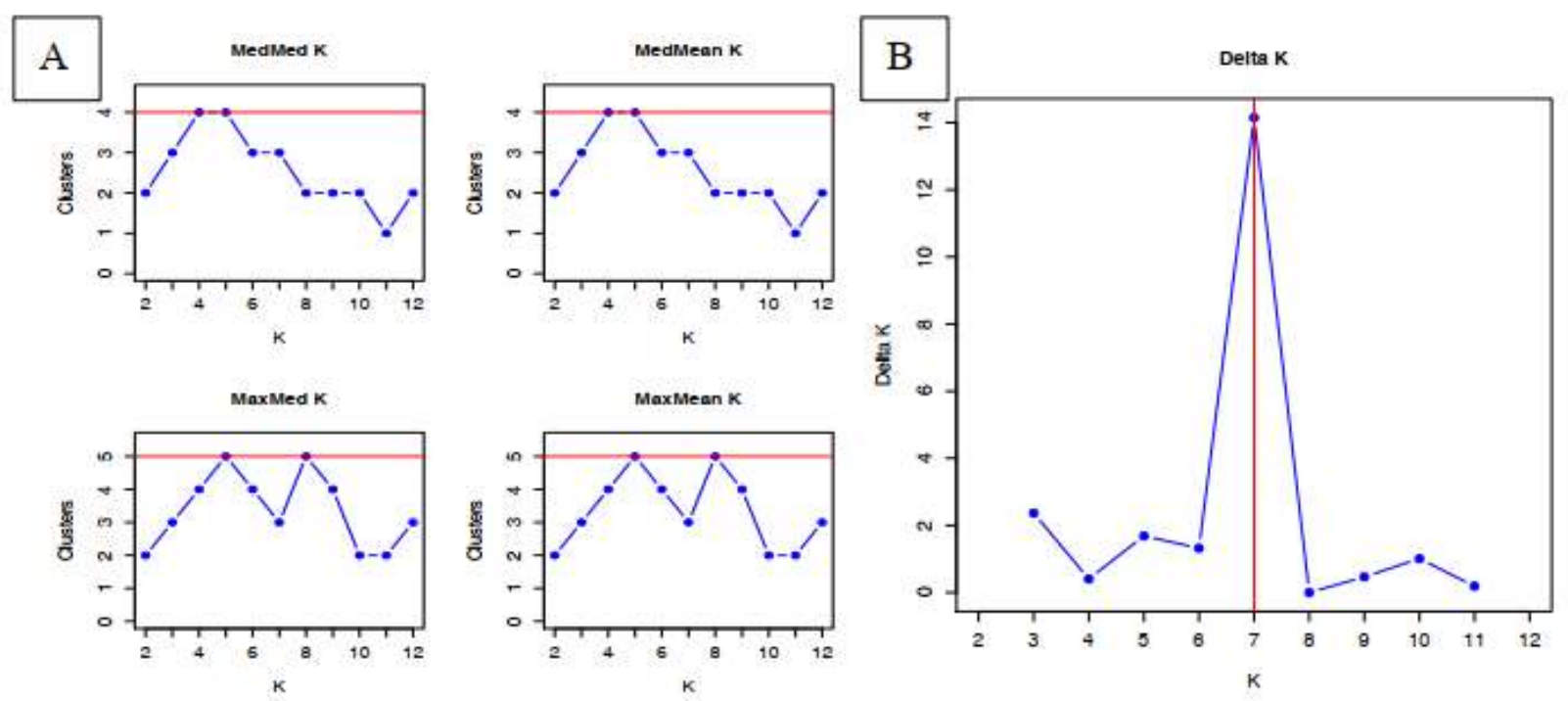

Figure 7 The best K estimation using Puechmaille Method (A) and Evanno Method (B

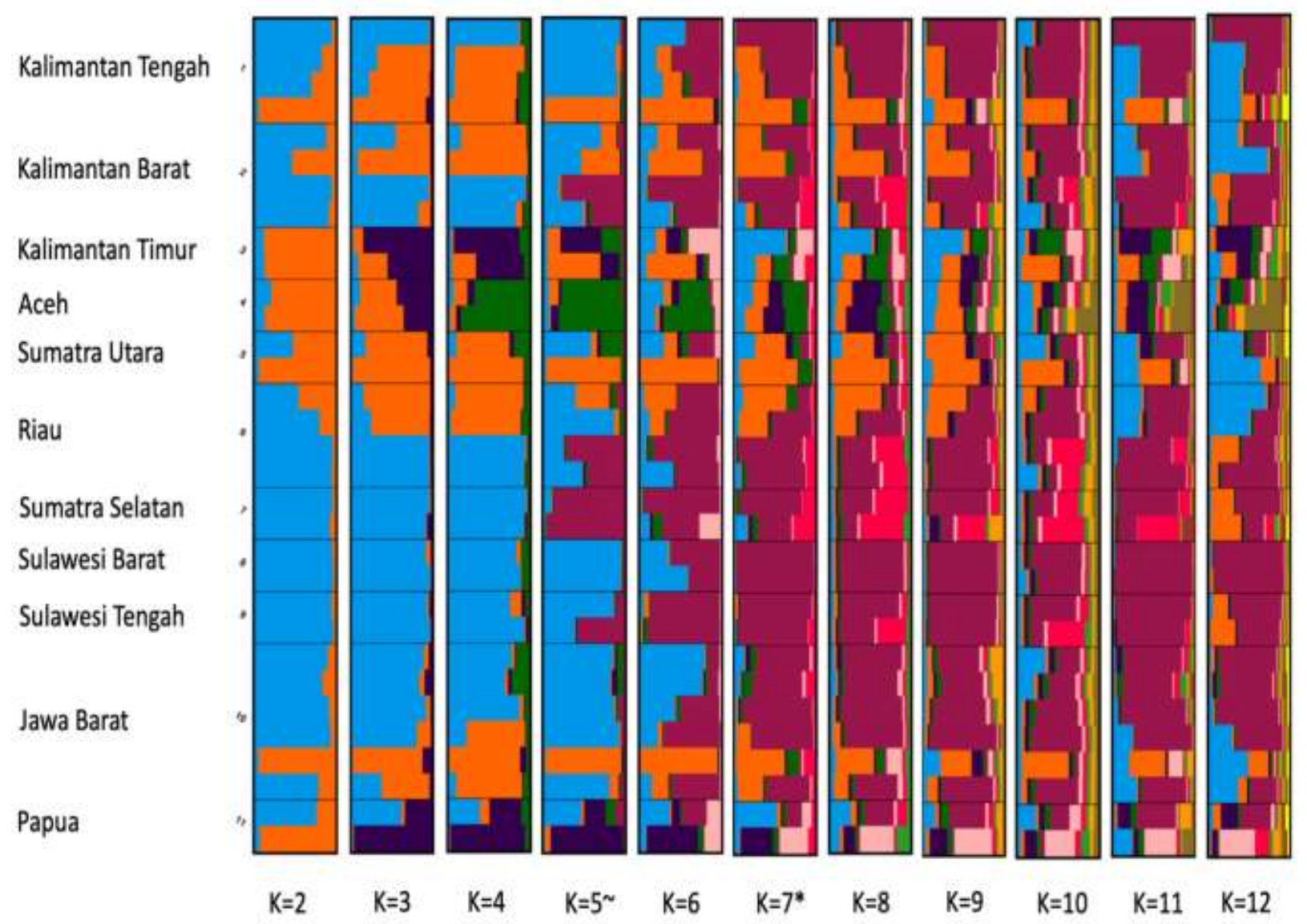

Figure 8 Population Structure based on $\mathrm{K}=2$ to $\mathrm{K}=12$

$\sim$ The best K based on Puechmaille Method ; *The best K based on Evanno Method 
[11] P. Genty, A. Garzon, F. Lucchini, G. Delvare, Polinizacion entomofila de la palma africana en Ame ricá tropical. Oleagineux. 41 (1986) 99-112

This study evidenced that there is high gene flow among the populations of E.kamerunicus in Indonesia based on combined independent molecular markers. This also may have played a role in shaping the observed weak structure detected in this study. In conclusion, E. kamerunicus between islands in Indonesia was not isolated by geographic.

\section{REFERENCES}

[1] P.G. Willmer, constraints on activity patterns in nectar-feeding insects. Ecol. Entomol. 8 (1983) 455-469

[2] C.M. Herrera, Daily patterns of pollinator activity, differential polli- nating effectiveness, and floral resource availability, in a summer-flowering Mediterranean shrub. Oikos. 58 (1990) 277-288

[3] P.G. Willmer, G. N. Stone, Behavioral, ecological, and physio- logical determinants of the activity patterns of bees, In Advances in the study of behavior, Elsevier, 2004, pp. 347-466

[4] D. Gottlieb, T. Keasar, A. Shmida, U. Motro, Possible foraging benefits of bimodal daily activity in Proxylocopa olivieri (Lepeletier) (Hymenoptera: Anthophoridae). Environ. Entomol. 34 (2005) 417-424

[5] G.N. Stone, P. G. Willmer, Warm-up rates and body temperatures in bees: the importance of body size, thermal regime and phylogeny. J. Exp. Biol. 147 (1989) 303-328

[6] H. Adam, M. Collin, F. Richaud, T. Beule, D. Cros, A. Omore, L. Nodichao, B. Nouy, J.W. Tregear, Environmetal regulation of sex determination in oil palm: Current knowledge and insight from other species, Ann. Bot. 108 (2011) $1517-1527$

[7] R.A. Syed, Studies on oil palm pollination by insects. Bull. Entomol. Res. 69 (1979) 213-224

[8] F.I. Opute, Identification of p.Methoxyally benzene in the pollen of the oil palm Elaeis guineensis Jacq. J. Exp. Bot. 26 (1975) 619-623.

[9] M.N. Lajis, Y. Hussein, R. F. Toia,. Extraction and identification of the main compound present in Elaeis guineensis flower volatiles. Pertanika. 8 (1985) 105-108.

[10] M.Y. Hussein, H. Lajis, A. Kinson, C.B. Teo, Laboratory and field evaluation on the attractancy of Elaeidobius kamerunicus (Faust) to 4allylanisole. PORIM Bull. (1989) 20-26.
[12] R.H.V.Corley, How much palm oil do we need? Environ. Sci. Policy. 12 (2009) 134-139

[13] R.A. Syed, H. Law, R.H.V. Corley, Insect pollination of oil palm: introduction, establishment and pollinating efficiency of Elaeidobius kamerunicus in Malaysia. Planter. 58 (1982) 547-561

[14] R. Desmier de Chenon, New data of the entomophily pollination of the oil palm in West Africa, 1981.

[15] D. Mariau, M. Houssou, R. Lecoustre, B. Ndigui, Oil palm polli- nating insects and fruitset rates in West Africa. Oleagineux. 46 (1991) 43-51

[16] R. Tandon, T.N. Manohara, B.H.M. Nijalingappa, K.R. Shivanna, Pollination and pollen-pistil interaction in oil palm, Elaeis guineensis. Ann. Bot. 87 (2001) 831-838

[17] J. Yue, Z. Yan, C. Bai, Z. Chen, W. Lin, F. Jiao, Pollination activity of Elaeidobius kamerunicus (Coleoptera: Curculionoidea) on Oil Palm on Hainan Island. Fla. Entomol. 98 (2015) 499-505

[18] D. Mariau, P. Genty,IRHO contribution to the study of oil palm insect pollinators in Africa, South-America and Indonesia. Oleagineux. 43

[19] C.M. Chinchilla-Lopez, D.L. Richardson, Polinizacion en palma aceitera (Elaeis guineensis Jacq.) en Centroame ricá. 1. Poblacion de insectos y conformacion de racimos. Turrialba. 40 (1990) $452-460$

[20] M. Prada, D. Molina, D. Villarroel, R. Barrios, A. Diaz, Effectiveness of two pollinator species of the genus Elaeidobius (Coleoptera: Curculionidae) in oil palm. Bioagro. 10 (1998) 310

[21] J.I.L. Moura, J. Cividanes, J.L. Pires, L.P. Santos, E.A. Santos, R.R. Valle, J.H.C. Delabie, Behavior of Curculionidae pollinators on oil palm inflorescences in the State of Bahia, Brazil. Agrotropica. 22 (2010) 45-50

[22] A. Estoup, T. Guillemaud, Reconstructing routes of invasion using genetic data: why, how and so what? Mol. Ecol. 19 (2010) 4113-4130

[23] G.K. Roderick, Geographic structure of insect populations: gene flow, phylogeography, and their uses. Annu. Rev. Entomol. 41 (1996) 263-290 (1988) 233-240 
number of clusters using multiple methods. Mol. Ecol. Res.18 (2018) 176-177

[36] S.J. Puechmaille, The program structure does not reliably recover the correct population structure when sampling is uneven: subsampling and new estimators alleviate the problem. Mol. Ecol. Res. 16 (2016) 608-627

[37] G. Evanno, S. Regnaut, J. Goudet, Detecting the number of clusters of individuals using the software structure: a simulation study. Mol. Ecol. 14 (2015) 2611-2620

[38] N.M. Kopelman, J. Mayzel, M. Jakobsson, N.A. Rosenberg, I. Mayrose, Clumpak: a program for identifying clustering modes and packaging population structure inferences across $\mathrm{K}$. Molecular Ecology Resources, 15 (5) (2015) 1179-1191. DOI: https://doi.org/10.111/17550998.12387

[39] J.A.Lewter, A.L. Szalanski, R.N. Nagoshi, R.L. Meagher, C.B. Owens, R.G. Luttrell, Genetic variation within and between strains of the fall armyworm, Spodoptera frugiperda (Lepidoptera: Noctuidae). Fla Entomol 89 (2006) 63-67

[40] J.C. Avise, Molecular markers, natural history and evolution. Chapman and Hall, New York, 1994, $511 \mathrm{p}$.

[41] J. Freeland (ed), Molecular ecology. West Sussex, Jonh Wiley \& Sons, 2005, pp. 388.

[42] P.D. Hebert, A. Cywinska, S.L. Ball, J.R. de Waard, Biological identifications through DNA barcodes. Proceedings of the Royal Society of London B: Biological Sciences, 270(1512) (2003) 313-321. DOI: https://doi.org/10.1098/rspb.2002. 2218

[43] S. Ratnasingham, P.D. Hebert, A DNA-based registry for all animal species: The Barcode Index Number (BIN) system. PLoS ONE, 8(7) (2013) e66213. DOI: https://doi.org/10.1371/ zjournal.pone.0066213

[44] R.D.J. Bakara, D. Buchori, R.Y.M. Kusumah, B. Sahari, A. Apriyanto, Genetic diversity of Elaeidobius kamerunicus Faust. (Coleoptera: Curculionidae) across geographic areas in Indonesia; implications for oil palm sustainibility.IOP conf series: Earth and Environmental Science, 2019, 325012003.

[45] V. Tambunan, Morphometry, Pollen load, and Genetic diversity of Elaeidobius kamerunicus Faust. (Coleoptera: Curculionidae) from Indonesia, Malaysia and Cameroon. Master's Thesis, IPB University, 2020. 